\title{
Proton Nuclear Magnetic Resonance Spectroscopy Analysis of Mixtures of Chlorhexidine with Different Oxidizing Agents Activated by Photon-Induced Photoacoustic Streaming for Root Canal Irrigation
}

\author{
Hatice Buyukozer Ozkan, DDS, PhD, ${ }^{1}$ Arslan Terlemez, DDS, PhD, ${ }^{2}$ and Ekim Onur Orhan, DDS, $\mathrm{PhD}^{3}$
}

\begin{abstract}
Objective: The aim of this in vitro study was to investigate the possible interactions between photon-induced photoacoustic streaming (PIPS ${ }^{\mathrm{TM}}$ )-activated oxidizing agents and $2 \%$ chlorhexidine digluconate.

Background data: There is no information about the safety of laser-activated oxidizing agents in combination usage with chlorhexidine gluconate.

Materials and methods: Groups were designed as follows G1: 98\% para-chloroaniline (PCA); G2: 2\% chlorhexidine (CHX); G3: 5.25\% sodium hypochlorite $(\mathrm{NaOCl})+2 \% \mathrm{CHX}$; G4: $5.25 \% \mathrm{NaOCl}$ (30 sec PIPS activated) $+2 \%$ CHX; G5: $5.25 \% \mathrm{NaOCl}\left(60 \mathrm{sec}\right.$ PIPS activated) $+2 \%$ CHX; G6: $3.5 \%$ chlorine dioxide $\left(\mathrm{ClO}_{2}\right)$ + 2\% CHX; G7: $3.5 \%\left(\mathrm{ClO}_{2}\right)\left(30 \mathrm{sec}\right.$ PIPS activated) +2\% CHX; G8: 3.5\% $\left(\mathrm{ClO}_{2}\right)(60 \mathrm{sec}$ PIPS activated $)+2 \%$ $\mathrm{CHX}$. The laser-irrigation protocol was performed with an erbium:yttrium-aluminum-garnet laser with a wavelength of $2940 \mathrm{~nm}$ equipped with a $140 \mathrm{~mm}$ long endodontic fiber tip (PIPS) using $10 \mathrm{~mJ}$ at $15 \mathrm{~Hz}(0.15 \mathrm{~W})$, per pulse operating outputs. Groups were analyzed with proton nuclear magnetic resonance spectroscopy, using PCA as an internal standard.
\end{abstract}

Results: No free PCA was formed in any groups of mixtures or after PIPS activation.

Conclusions: Mixing of 3.5\% $\mathrm{ClO}_{2}$ and $2 \% \mathrm{CHX}$ does not form bulky precipitates, unlike the mixture $\mathrm{NaOCl}+$ CHX. PIPS activation does not cause changes in reactions of oxidizing agents.

Keywords: chlorhexidine, chlorine dioxide, NMR spectroscopy, photon-induced photoacoustic streaming, sodium hypochlorite

\section{Introduction}

$\mathbf{T}$ HE PURPOSE OF endodontic treatment is to remove pulp tissue and microorganisms from root canals. Because of the complicated anatomy of root canals, uncleaned canal space can remain after root canal instrumentation. ${ }^{1}$ Thus, root canal irrigation is a crucial step for root canal disinfection and debris removal. ${ }^{2}$ Sodium hypochlorite $(\mathrm{NaOCl})$ is one of the most widely used irrigation solutions in root canal treatment because of its antibacterial effect and organic tissue dissolution capacity. However, the efficiency of $\mathrm{NaOCl}$ is directly related to its concentration. The $\mathrm{NaOCl}$ should be used at low concentration because it can be toxic on periapical tissues at high concentrations. ${ }^{3,4}$ However, there is decreased efficiency of $\mathrm{NaOCl}$ at lower concentrations. The efficiency may be regained with strategies such as agitation/activation methods or combination with additional agents. In addition, studies are underway to discover alternative oxidizing agents to hypochlorite to eliminate its disadvantages.

Chlorine dioxide $\left(\mathrm{ClO}_{2}\right)$ is a commonly used biocompatible disinfectant, bleaching solution, and oxidizing agent. It is used in the food industry, veterinary medicine, water treatment, surface disinfection, and mouth care products. ${ }^{5-7} \mathrm{ClO}_{2}$ at low concentrations is able to dissolve organic tissues without causing toxic or allergenic reactions. ${ }^{8,9} \mathrm{~A}$ recent study has reported that $\mathrm{ClO}_{2}$ may be an alternative root canal irrigation agent in root canal treatment instead of $\mathrm{NaOCl}$ because of its antimicrobial activity, biocompatibility, and

\footnotetext{
${ }^{1}$ Department of Endodontics, Faculty of Dentistry, Alanya Alaaddin Keykubat University, Antalya, Turkey.

${ }^{2}$ Department of Endodontics, Faculty of Dentistry, Necmettin Erbakan University, Konya, Turkey.

${ }^{3}$ Department of Endodontics, Faculty of Dentistry, Eskişehir Osmangazi University, Eskişehir, Turkey.
} 
organic dissolution capacity. ${ }^{8-10}$ Throughout its oxidation process, toxic byproducts are not formed. ${ }^{10}$

Laser-activated irrigation (LAI) has been introduced for activating irrigation solutions through the transfer of pulsed energy. ${ }^{11,12}$ In principle, photon-induced photoacoustic streaming $\left(\mathrm{PIPS}^{\mathrm{TM}}\right)$ is an LAI technique utilizing minimal ablative energy levels. PIPS can improve the efficiency of irrigation solutions at lower concentrations. ${ }^{13}$ The PIPS technique utilizes an erbium:yttrium-aluminum-garnet (Er:YAG) laser source, including a $3 \mathrm{~mm}$ polyamide sheath and a tapered tip, designed for access and cavity penetration. The Er:YAG laser source uses subablative parameters. Thus, it is able to activate the total amount of irrigation solution within the root canal. PIPS generates strong photoacoustic shock waves into the irrigation solution. ${ }^{13}$ Therefore, the PIPS technique has been reported to increase the cleaning efficiency of the root canal system better than conventional needle irrigation. ${ }^{14,15}$

Chlorhexidine (CHX) is a broad-spectrum antimicrobial agent. Low concentrations are commonly used as oral antisepsis and root canal disinfectant. ${ }^{16} \mathrm{CHX}$ is the preferred agent for use during the final irrigation because of its residual antimicrobial effects on dentine walls. ${ }^{17,18}$ However, CHX should not be introduced after the $\mathrm{NaOCl}$ irrigation without intermittent flushing/dilution in the root canal. When $\mathrm{CHX}$ and $\mathrm{NaOCl}$ are mixed without dilution, a brown-colored precipitate is formed. This precipitate is hard to eliminate from the root canal walls. ${ }^{19}$ There are conflicting results about the molecular structure of the brown precipitate. $^{20-22}$ Para-chloroaniline (PCA) or 4-chloroaniline is a degradation product of CHX molecular structure. ${ }^{20,21}$ However, Orhan et al. ${ }^{22}$ showed that free PCA did not form after the interaction between $\mathrm{NaOCl}$ and CHX. PCA is a toxic and carcinogenic molecule, but fortunately, $\mathrm{CHX}$ is not degraded to free PCA after interacting with $\mathrm{NaOCl}^{20,22}$ However, the effects of PIPS-assisted LAI on irrigation agents are still unknown.

The aim of this study was to analyze the PIPS-activated oxidizing agents and their interactions with CHX. The first null hypothesis was that the oxidation agents and their CHX mixtures did not contain free PCA. The second null hypothesis was that PIPS activation did not affect the interactions of irrigation solutions.

\section{Materials and Methods}

\section{Preparation of solutions}

The following stock solutions manufactured for dental purposes were used: 5.25\% fresh $\mathrm{NaOCl}$ (aq) (Promida Co., Eskişehir, Turkey) and 2\% CHX (aq) (ProChex; Promida Co.). Commercially accessible $3.5 \%$ fresh $\mathrm{ClO}_{2}$ (aq) (Cemmox, Denizli, Turkey) and 98\% PCA (4-chloroaniline; Sigma-Aldrich, St. Louis, MO) in powder form were also used for experiments.

Mixtures were created by introducing $1 \mathrm{~mL} 2 \%$ CHX solution to $1 \mathrm{~mL}$ chlorinated solution per group in Eppendorf tubes. The mixture formed by the addition of two solutions was adjusted to $2 \mathrm{~mL}$. Solutions were mixed in Eppendorf tubes at $25^{\circ} \mathrm{C}$. Additional solutions were delivered using an automatic pipette (Maxipettor Eppendorf; Thomas Scientific, Swedesboro, NJ) and mixing by using a capillary laboratory pipette for $60 \mathrm{sec}$.

\section{PIPS protocol}

The previously described laser-irrigation protocol was performed with an Er:YAG laser with a wavelength of $2940 \mathrm{~nm}$ (LightWalker; Fotona, Ljubljana, Slovenia) equipped with a $140 \mathrm{~mm}$ long endodontic fiber tip of PIPS using $10 \mathrm{~mJ}$ at $15 \mathrm{~Hz}(0.15 \mathrm{~W})$, per pulse operating outputs. ${ }^{13}$ The fiber tip was placed $3 \mathrm{~mm}$ deep into the solutions to simulate clinical usage. Total activation time was either 30 or $60 \mathrm{sec}$, as suggested by various authors who use PIPS. $^{23,24}$ The PIPS was operated in $1 \mathrm{~mL}$ of solution in accordance with suggestions by authors who use LAI.

\section{$\mathrm{pH}$ measurement}

The $\mathrm{pH}$ value and temperature of each tested solution was measured using a pH meter (WTW inoLab 7110; Weilheim, Germany) before PIPS activation, after 30 and $60 \mathrm{sec}$ of PIPS activation, and after mixing.

\section{Extraction of precipitates}

A previous extraction and solvation method was used in this study using analytical grade ethyl acetate. ${ }^{22,25}$ Precipitates were extracted three times in $15 \mathrm{~mL}$ of ethyl acetate and were added into an organic solvent. The organic layer of the precipitates was detached and dehydrated with $\mathrm{Na}_{2} \mathrm{SO}_{4}$. The solvent was removed, and the solid part of the precipitates was then obtained under reduced pressure.

\section{Proton nuclear magnetic resonance ('HNMR) spectroscopy}

Nuclear magnetic resonance (NMR) spectra were obtained using a JEOL RESONANCE Spectrometer (ECZ 500R; JEOL Co., Ltd., Tokyo, Japan) utilizing a $5 \mathrm{~mm}$ BBO probe at $298 \mathrm{~K}$ and $11.75 \mathrm{~T}$. The operating frequency was $500.13 \mathrm{MHz}$ for a ${ }^{1} \mathrm{H}$ nucleus. Each spectrum was recorded in deuterated dimethyl sulfoxide (d6-DMSO) separately using $\mathrm{C}_{4} \mathrm{H}_{12} \mathrm{Si}$ as an external standard in a ${ }^{1} \mathrm{HNMR}$ spectroscopy unit. $^{22}$

\section{Results}

The color of each group was as follows: $2 \% \mathrm{CHX}$ and $5.25 \% \mathrm{NaOCl}$ were colorless; $3.5 \% \mathrm{ClO}_{2}$ was yellowish,

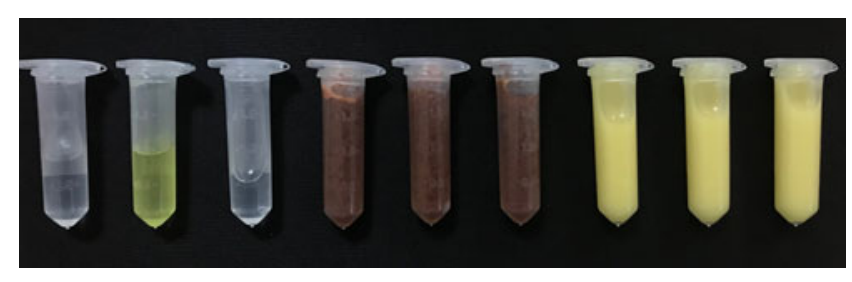

FIG. 1. Appearances of the solutions prepared (left to right): $5.25 \% \mathrm{NaOCl} ; 3.5 \% \mathrm{ClO}_{2} ; 2 \% \mathrm{CHX} ; 5.25 \% \mathrm{NaOCl}$ mixed with $2 \%$ CHX; $5.25 \% \mathrm{NaOCl}$ activated by $30 \mathrm{sec}$ PIPS, mixed with $2 \% \mathrm{CHX} ; 5.25 \% \mathrm{NaOCl}$ activated by $60 \mathrm{sec}$ PIPS, mixed with $2 \% \mathrm{CHX} ; 3.5 \% \mathrm{ClO}_{2}$ mixed with $2 \% \mathrm{CHX} ; 3.5 \% \mathrm{ClO}_{2}$ activated by $30 \mathrm{sec}$ PIPS, mixed with $2 \% \mathrm{CHX} ; 3.5 \% \mathrm{ClO}_{2}$ activated by $60 \mathrm{sec}$ PIPS, mixed with $2 \%$ CHX. CHX, chlorhexidine; $\mathrm{ClO}_{2}$, chlorine dioxide; $\mathrm{NaOCl}$, sodium hypochlorite; PIPS ${ }^{\mathrm{TM}}$, photon-induced photoacoustic streaming. 
TABle 1. EXPERIMENTAL Groups

\begin{tabular}{llcl}
\hline No. & \multicolumn{1}{c}{ Groups } & Precipitate & \multicolumn{1}{c}{ Color } \\
\hline 1 & $98 \%$ PCA (solid) & N/A & White \\
2 & $2 \% \mathrm{CHX} \mathrm{(aqueous} \mathrm{solution)}$ & N/A & Noncolored \\
3 & $5.25 \% \mathrm{NaOCl}+2 \% \mathrm{CHX}$ & Yes & Brownish \\
4 & $5.25 \% \mathrm{NaOCl}+30 \mathrm{sec} \mathrm{PIPS}+2 \% \mathrm{CHX}$ & Yrownish \\
5 & $5.25 \% \mathrm{NaOCl}+60 \mathrm{sec} \mathrm{PIPS}+2 \% \mathrm{CHX}$ & Yes & Brownish \\
6 & $3.5 \% \mathrm{ClO}_{2}+2 \% \mathrm{CHX}$ & No & Straw-colored or yellowish \\
7 & $3.5 \% \mathrm{ClO}_{2}+30 \mathrm{sec}$ PIPS $+2 \% \mathrm{CHX}$ & No & Straw-colored or yellowish \\
8 & $3.5 \% \mathrm{ClO}_{2}+60 \mathrm{sec}$ PIPS $+2 \% \mathrm{CHX}$ & No & Straw-colored or yellowish \\
\hline
\end{tabular}

CHX, chlorhexidine; $\mathrm{ClO}_{2}$, chlorine dioxide; $\mathrm{NaOCl}$, sodium hypochlorite; PCA, para-chloroaniline or 4-chloroaniline; PIPS ${ }^{\mathrm{TM}}$, photoninduced photoacoustic streaming with erbium:yttrium-aluminum-garnet activation.

$3.5 \% \mathrm{ClO}_{2}+2 \% \mathrm{CHX}, 3.5 \% \mathrm{ClO}_{2}+30 \mathrm{sec}$ PIPS $+2 \% \mathrm{CHX}$ and $3.5 \% \mathrm{ClO}_{2}+60 \mathrm{sec}$ PIPS $+2 \% \mathrm{CHX}$ were straw colored; an $5.25 \% \mathrm{NaOCl}+2 \% \mathrm{CHX}, 5.25 \% \mathrm{NaOCl}+30 \mathrm{sec}$ PIPS $+2 \% \mathrm{CHX}$, and $5.25 \% \mathrm{NaOCl}+60 \mathrm{sec}$ PIPS + $2 \% \mathrm{CHX}$ were brownish (Fig. 1 and Table 1).

The $\mathrm{pH}$ values of the single solutions at room temperature are given in Table 2. The $\mathrm{pH}$ values of the mixtures at room temperature are given in Table 3 . After 30 and $60 \mathrm{sec}$ of PIPS activation, the temperatures and $\mathrm{pH}$ values of the solutions increased. Although CHX was not activated by PIPS during the experiment, $\mathrm{pH}$ and temperature changes were also examined separately.

${ }^{1}$ HNMR spectral data are represented in Fig. 2. In $98 \%$ PCA, the spectrum revealed two doublets at 7.00 and $6.55 \mathrm{ppm}$ for an aromatic ring and one singlet signal for an amino $\left(-\mathrm{NH}_{2}\right)$ group at $5.23 \mathrm{ppm} .^{22,25}$ The datasets (raw spectral data) are also available in the Supplementary Data.

The d6-DMSO peaks were observed as a singlet at $2.5 \mathrm{ppm}$, and water peaks were observed at $3.37 \mathrm{ppm}$ in all spectra. In $\mathrm{NaOCl}$ mixtures, both the aromatic and the aliphatic region of $\mathrm{CHX}$ changed. The shifts in the aromatic region were recorded between 7.30 and $7.80 \mathrm{ppm}$. The doublet observed in the aliphatic region of the CHX spectrum between 0.9 and $1.1 \mathrm{ppm}$ and a broad peak at $2.95 \mathrm{ppm}$ were lost after the $\mathrm{NaOCl}$ mixture was added. In $\mathrm{ClO}_{2}$ mixtures, the aliphatic region of $\mathrm{CHX}$ was less affected, and the aromatic region changed only minimally. There was a reaction shown only by peaks between 6 and 8 ppm, and the peaks between 9 and $10 \mathrm{ppm}$ disappeared in the aromatic region.

${ }^{1}$ HNMR spectral data revealed that no free PCA existed in any solutions, mixtures, or precipitates. The PIPS activation did not cause changes in the structure of precipitates or mixtures.

TABle 2. PH AND Temperatures of Solutions

\begin{tabular}{lccc}
\hline Groups & $\mathrm{ClO}_{2}$ & $\mathrm{NaOCl}$ & $\mathrm{CHX}$ \\
\hline Initial & & & \\
$\mathrm{pH}$ & 4.74 & 9.26 & 5.96 \\
${ }^{\circ} \mathrm{C}$ & 26.2 & 26.2 & 26.2 \\
$30 \mathrm{sec}$ PIPS & & & \\
pH & 4.75 & 9.27 & 6.00 \\
${ }^{\circ} \mathrm{C}$ & 26.8 & 26.8 & 26.8 \\
$60 \mathrm{sec}$ PIPS & & & \\
pH & 4.75 & 9.27 & 6.01 \\
${ }^{\circ} \mathrm{C}$ & 27.8 & 27.7 & 27.7 \\
\hline
\end{tabular}

\section{Discussion}

NMR spectroscopy can examine molecules without disintegrating their molecular structures. NMR spectral analysis allows comparing peak intensity and location for fine-tuned concentration values of any experimental spectrum. When signals are arranged at the same $\mathrm{pH}$ or field strength, then the experimental material is verified to exist in that compound. Therefore, the mixtures and standard molecules were analyzed with their HNMR spectral data (singlet, doublet, etc.) in this study and compared. All spectral data were recorded under the same magnetic field strength at $500.13 \mathrm{MHz}$ and all analyses were performed individually. No databases or libraries containing spectral data were used.

The ${ }^{1} \mathrm{HNMR}$ spectra of pure PCA is fundamental to visualizing an amino $\left(-\mathrm{NH}_{2}\right)$ signal at 5-5.5 ppm. ${ }^{22,25-27}$ Therefore, Thomas and Sem used pure PCA as the "internal standard" or "control" in their "HNMR spectroscopy study. ${ }^{26}$ Spectral data (peaks of the spectrum pattern as a singlet, doublet, etc.) can only be compared with an internal standard or spectral databases. In previous studies, Orhan et al., ${ }^{22}$ Irmak et al., ${ }^{25}$ and Nocca et al. ${ }^{28}$ used pure PCA as an internal standard in ${ }^{1} \mathrm{HNMR}$ spectroscopy analysis of the same kind of precipitate. In other literature, the spectral analyses of the irrigation agents and their interactions were evaluated using only a single sample per experimental group. There have not been any exceptions to this sample quantity in the literature. ${ }^{22,25,26}$ Further comparisons with other interaction scenarios could be considered in future designs.

A characteristic of the aromatic subspectrum of $98 \%$ PCA is that it has a primary amino $\left(-\mathrm{NH}_{2}\right)$ singlet at 5.0-5.5 ppm; ${ }^{22,25}$ thus, existence of an $-\mathrm{NH}_{2}$ singlet indicates free PCA in the experimental material. The mixture groups and $2 \% \mathrm{CHX}$ revealed dissimilar aromatic doublet peaks and a singlet of $98 \%$ PCA. Regardless of the oxidizing agent, we did not detect free PCA in $5.25 \% \mathrm{NaOCl}, \mathrm{CHX}$ mixtures, or $2 \% \mathrm{CHX}$. Our results are in agreement with previous reports. $^{22,25,26}$ Therefore, the first null hypothesis is accepted.

The specific amino signals of the ${ }^{1}$ HNMR spectrum for 98\% PCA were compared with those from the mixture of

Table 3. PH and Temperatures of Mixtures

\begin{tabular}{lcc} 
Groups & $p H$ & ${ }^{\circ} \mathrm{C}$ \\
\hline $\mathrm{ClO}_{2}+\mathrm{CHX}$ & 4.78 & 27.8 \\
$\mathrm{NaOCl}+\mathrm{CHX}$ & 9.75 & 27.7 \\
\hline
\end{tabular}



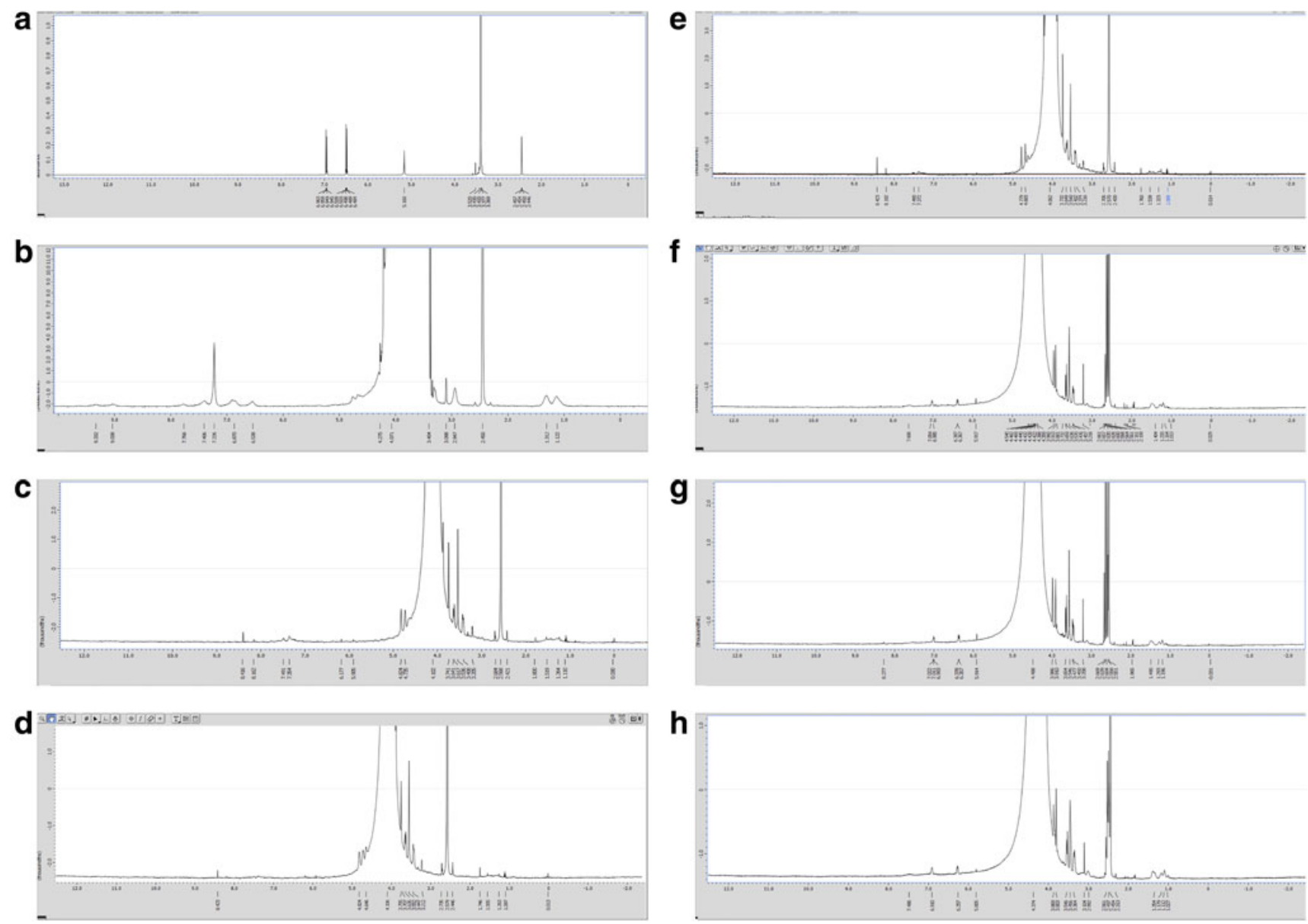

FIG. 2. ${ }^{1} \mathrm{H}$ NMR experiments showed no free PCA was found in the degradation of CHX: (a) Reference spectrum of PCA in d6-DMSO. (b) Reference spectrum of $2 \mathrm{~mL} 2 \% \mathrm{CHX}$ in d6-DMSO. (c) ${ }^{1} \mathrm{H}$ NMR spectrum acquired after addition of $1 \mathrm{~mL} 2 \% \mathrm{CHX}(\mathrm{aq})$ to $1 \mathrm{~mL} 5.25 \% \mathrm{NaOCl}(\mathrm{aq})$. (d) ${ }^{1} \mathrm{H}$ NMR spectrum acquired after addition of $1 \mathrm{~mL} 2 \% \mathrm{CHX}(\mathrm{aq})$ to activated $1 \mathrm{~mL} 5.25 \% \mathrm{NaOCl}$ (aq) by $30 \mathrm{sec}$ PIPS. (e) ${ }^{1} \mathrm{H}$ NMR spectrum acquired after addition of $1 \mathrm{~mL} 2 \% \mathrm{CHX}$ (aq) to activated $1 \mathrm{~mL} 5.25 \% \mathrm{NaOCl}(\mathrm{aq})$ by $60 \mathrm{sec}$ PIPS. (f) ${ }^{1} \mathrm{H} \mathrm{NMR}$ spectrum acquired after addition of $1 \mathrm{~mL} 2 \% \mathrm{CHX}$ (aq) to $1 \mathrm{~mL} 3.5 \% \mathrm{ClO}_{2}$ (aq). (g) ${ }^{1} \mathrm{H}$ NMR spectrum acquired after addition of $1 \mathrm{~mL} 2 \% \mathrm{CHX}(\mathrm{aq})$ to activated $1 \mathrm{~mL} 3.5 \% \mathrm{ClO}_{2}$

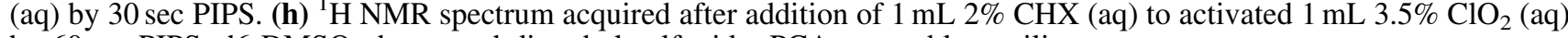
by 60 sec PIPS. d6-DMSO, deuterated dimethyl sulfoxide; PCA, para-chloroaniline.

$2 \% \mathrm{CHX}$ and $3.5 \% \mathrm{ClO}_{2}$ for the first time in this study. When $2 \% \mathrm{CHX}$ was added to $3.5 \% \mathrm{ClO}_{2}$, no precipitation occurred. However, a weak nonacid-base reaction was observed as a result of the mixture; the color of the $3.5 \% \mathrm{ClO}_{2}$ turned from a yellowish color to a cloudy straw color. Previous studies have reported the characteristics of $\mathrm{ClO}_{2}$. It is antibacterial, it dissolves organic tissue, and it is nontoxic. ${ }^{8-10}$ However, there is limited information about the reactions of $\mathrm{ClO}_{2}$. Herczegh et al. ${ }^{29}$ reported the results of an in vitro study using an high performance liquid chromatography-mass spectroscopy (HPLC/MS) method, which showed that free PCA did not appear after mixing of $1 \% \mathrm{CHX}$ and $0.12 \%$ hyper-pure $\mathrm{ClO}_{2}$. That supports our findings on free PCA. Although $\mathrm{NaOCl}$ and $\mathrm{ClO}_{2}$ are both oxidizing agents, they could have different reactions with $\mathrm{CHX} .{ }^{30}$ In agreement with that previous report, precipitation-like reactions did not occur in our study. A brown-colored precipitate could have a negative influence on the penetration of root canal sealer on dentin tubules and could cause discoloration. It could also be difficult to remove. ${ }^{19}$ Thus, the precipitation could negatively affect the root canal filling and postendodontic restoration quality. ${ }^{19}$ The baseline mixing procedures were tested in our study, and free PCA was analyzed using HNMR spectroscopy. Further studies are needed to understand the clinical effects of $\mathrm{ClO}_{2}$ and its combinations with other irrigation agents on root canal walls. A previous study that compared $2.5 \% \mathrm{NaOCl}$ and $13.8 \% \mathrm{ClO}_{2}$ found that $2.5 \% \mathrm{NaOCl}$ caused roughness of the root canal wall. ${ }^{30}$

In this study, it was observed that $\mathrm{pH}$ values of oxidizing agents increased by $1 \%$ with PIPS activation. The effect of $\mathrm{pH}$ change on chlorine-containing compounds has been previously investigated, and it has been reported that this affects their organic-tissue-dissolving and antibacterial properties. ${ }^{31}$ However, because an increase of $1 \%$ does not significantly change the alkaline or acid properties of the solution, it can be concluded that PIPS activation has no effect on $\mathrm{pH}$ within the parameters of our study. However, further studies are needed on this subject.

This study found increased temperature and $\mathrm{pH}$ of $\mathrm{CHX}$ after PIPS activation. Although the $\mathrm{pH}$ of $\mathrm{CHX}$ increased 
with PIPS activation in this study, it is known that the optimal antibacterial effect of $\mathrm{CHX}$ occurs between $\mathrm{pH} 5.5$ and 7. ${ }^{32}$ Mixtures of PIPS-activated CHX were not examined in this study, but the effects of PIPS on all solutions used in the experiment were investigated separately. Basrani et al. investigated the effect of temperature changes on $\mathrm{CHX}$ and reported that $\mathrm{CHX}$ turned white when heated to $37^{\circ} \mathrm{C}$, but a yellowish color was observed at $45^{\circ} \mathrm{C} .{ }^{33}$ However, further studies on the effects of $\mathrm{pH}$ and temperatures are needed.

Different agitation techniques are used to increase the effectiveness of endodontic irrigation solutions. ${ }^{12}$ PIPS activation has been reported to be more efficient than the other activation methods. ${ }^{11}$ Guneser et al. have reported that PIPS activation of $5.25 \% \mathrm{NaOCl}$ increases the efficiency of organic tissue dissolution more than a technique using a sonic activation system and an Er:YAG laser using an endodontic fiber tip activation. ${ }^{34}$ Similarly, Peters et al. have reported PIPS activation of $6 \% \mathrm{NaOCl}$ eliminated more biofilm than ultrasonic activation and conventional irrigation techniques. ${ }^{12}$ Golob et al. have reported that PIPS activation of $5 \% \mathrm{NaOCl}$ is an effective method for elimination of $\mathrm{En}$ terococcus faecalis. ${ }^{35}$ In the PIPS technique, the use of subablative energy $(20 \mathrm{~mJ})$ produces a high peak power of $400 \mathrm{~W}$, causing an explosion-implosion phenomenon within the irrigation solution. The primary thermal effect of laser energy absorbed in irrigation solution leads to superheating of the irrigant up to the boiling point and formation of vapor bubbles. ${ }^{35}$ This phenomenon explains the temperature changes in this study. $\mathrm{ClO}_{2}$ is a highly unstable molecule. Therefore, $\mathrm{ClO}_{2}$ reactions were tested by using PIPS activation as an efficient agitation method. Although $\mathrm{ClO}_{2}$ temperature increases, the PIPS activation did not cause any change in the structure of the precipitates and mixtures in this study. Thus, the second null hypothesis is accepted. The mixture of PIPS-activated $3.5 \% \mathrm{ClO}_{2}$ and $2 \% \mathrm{CHX}$ was analyzed. In this experiment, $3.5 \% \mathrm{ClO}_{2}$ mixtures did not form brown precipitates; instead, the color of the mixtures was observed to turn into cloudy light yellow.

\section{Conclusions}

Within the limitations of this in vitro study the following conclusions can be drawn:

- Mixing of $3.5 \% \mathrm{ClO}_{2}$ and $2 \% \mathrm{CHX}$ does not form any precipitate.

- The precipitate formed after $5.25 \% \mathrm{NaOCl}$ and $2 \%$ CHX 11 mixed does not yield free PCA.

- PIPS activation does not cause changes in reactions of oxidizing agents.

\section{Acknowledgments}

The authors thank Dr. Gökhan Dikmen and Dr. Okan Uslu for the valuable contribution of the proton nuclear magnetic spectroscopy analysis.

\section{Author Disclosure Statement}

No competing financial interests exist.

\section{Funding Information}

No funding was received for this article.

\section{Supplementary Material}

Supplementary Data

\section{References}

1. Peters OA, Laib A, Göhring TN, Barbakow F. Changes in root canal geometry after preparation assessed by highresolution computed tomography. J Endod 2001;27:1-6.

2. Qing Y, Akita Y, Kawano S, Kawazu S, Yoshida T, Sekine I. Cleaning efficacy and dentin micro-hardness after root canal irrigation with a strong acid electrolytic water. J Endod 2006;32:1102-1106.

3. Pashley E, Birdsong N, Bowman K, Pashley DH. Cytotoxic effects of $\mathrm{NaOCl}$ on vital tissue. J Endod 1985;11:525528.

4. Clarkson RM, Kidd B, Evans GE, Moule AJ. The effect of surfactant on the dissolution of porcine pulpal tissue by sodium hypochlorite solutions. J Endod 2012;38:12571260.

5. Oliver S, Lewis M, Ingle T, Gillespie B, Matthews K. Prevention of bovine mastitis by a premilking teat disinfectant containing chlorous acid and chlorine dioxide. J Dairy Sci 1993;76:287-292.

6. Frascella J, Gilbert RD, Fernandez P, Hendler J. Efficacy of a chlorine dioxide-containing mouthrinse in oral malodor. Compend Contin Educ Dent 2000;21:241-244, 246, 248 passim; quiz 256.

7. Kreske AC, Ryu J-H, Beuchat LR. Evaluation of chlorine, chlorine dioxide, and a peroxyacetic acid-based sanitizer for effectiveness in killing Bacillus cereus and Bacillus thuringiensis spores in suspensions, on the surface of stainless steel, and on apples. J Food Prot 2006;69:1892-1903.

8. Cobankara FK, Ozkan HB, Terlemez A. Comparison of organic tissue dissolution capacities of sodium hypochlorite and chlorine dioxide. J Endod 2010;36:272-274.

9. Nishikiori R, Nomura Y, Sawajiri M, Masuki K, Hirata I, Okazaki M. Influence of chlorine dioxide on cell death and cell cycle of human gingival fibroblasts. J Dent 2008;36: 993-998.

10. Herczegh A, Ghidan Á, Friedreich D, Gyurkovics M, Bendö Z, Lohinai Z. Effectiveness of a high purity chlorine dioxide solution in eliminating intracanal Enterococcus faecalis biofilm. Acta Microbiol Immunol Hung 2013;60: 63-75.

11. de Groot SD, Verhaagen B, Versluis M, Wu MK, Wesselink PR, van der Sluis LW. Laser-activated irrigation within root canals: cleaning efficacy and flow visualization. Int Endod J 2009;42:1077-1083.

12. Peters OA, Bardsley S, Fong J, Pandher G, Divito E. Disinfection of root canals with photon-initiated photoacoustic streaming. J Endod 2011;37:1008-1012.

13. DiVito E, Lloyd A. ER:YAG laser for 3-dimensional debridement of canal systems: use of Photon-Induced Photoacoustic Streaming. Dent Today 2012;31:122, 124-127.

14. DiVito E, Peters OA, Olivi G. Effectiveness of the erbium: YAG laser and new design radial and stripped tips in removing the smear layer after root canal instrumentation. Lasers Med Sci 2012;27:273-280.

15. Peeters HH, Suardita K. Efficacy of smear layer removal at the root tip by using ethylenediaminetetraacetic acid and erbium, chromium: yttrium, scandium, gallium garnet laser. J Endod 2011;37:1585-1589.

16. Haapasalo M, Shen Y, Qian W, Gao Y. Irrigation in endodontics. Dent Clin North Am 2010;54:291-312. 
17. Zehnder M. Root canal irrigants. J Endod 2006;32:389398.

18. Rôças IN, Provenzano JC, Neves MA, Siqueira Jr. JF. Disinfecting effects of rotary instrumentation with either $2.5 \%$ sodium hypochlorite or $2 \%$ chlorhexidine as the main irrigant: a randomized clinical study. J Endod 2016;42: 943-947.

19. Bui TB, Baumgartner JC, Mitchell JC. Evaluation of the interaction between sodium hypochlorite and chlorhexidine gluconate and its effect on root dentin. J Endod 2008;34: 181-185.

20. Nowicki JB, Sem DS. An in vitro spectroscopic analysis to determine the chemical composition of the precipitate formed by mixing sodium hypochlorite and chlorhexidine. J Endod 2011;37:983-988.

21. Basrani BR, Manek S, Sodhi RN, Fillery E, Manzur A. Interaction between sodium hypochlorite and chlorhexidine gluconate. J Endod 2007;33:966-969.

22. Orhan EO, Irmak Ö, Hür D, Yaman BC, Karabucak B. Does para-chloroaniline really form after mixing sodium hypochlorite and chlorhexidine? J Endod 2016;42:455-459.

23. Pedulla E, Genovese C, Campagna E, Tempera G, Rapisarda E. Decontamination efficacy of photon-initiated photoacoustic streaming (PIPS) of irrigants using low-energy laser settings: an ex vivo study. Int Endod J 2012;45: 865-870.

24. Olivi G, DiVito E. Photoacoustic endodontics using PIPS ${ }^{\mathrm{TM}}$ : experimental background and clinical protocol. J Laser Health Acad 2012;1:22-25.

25. Irmak Ö, Orhan EO, Görgün K, Yaman BC. Nuclear magnetic resonance spectroscopy and infrared spectroscopy analysis of precipitate formed after mixing sodium hypochlorite and QMix 2in1. PLoS One 2018;13:e0202081.

26. Thomas JE, Sem DS. An in vitro spectroscopic analysis to determine whether para-chloroaniline is produced from mixing sodium hypochlorite and chlorhexidine. J Endod 2010; 36:315-317.

27. Orhan E, Irmak O. Comments on misinterpretation of the proton nuclear magnetic resonance spectroscopic data of a previous study. Int Endod J 2019;52:1397-1398.

28. Nocca G, Ahmed HMA, Martorana GE, et al. Chromographic analysis and cytotoxic effects of chlorhexidine and sodium hypochlorite reaction mixtures. J Endod 2017;43: $1545-1552$.
29. Herczegh A, Palcsó B, Lohinai Z, Zelkó R. Tracking of the degradation process of chlorhexidine digluconate and ethylenediaminetetraacetic acid in the presence of hyperpure chlorine dioxide in endodontic disinfection. J Pharm Biomed Anal 2019;164:360-364.

30. Ballal NV, Khandewal D, Karthikeyan S, Somayaji K, Foschi F. Evaluation of chlorine dioxide irrigation solution on the microhardness and surface roughness of root canal dentin. Eur J Prosthodont Rest Dent 2015;23:P135-P140.

31. Rossi-Fedele G, Guastalli AR, Doğramacı E, Steier L, De Figueiredo J. Influence of $\mathrm{pH}$ changes on chlorine-containing endodontic irrigating solutions. Int Endod J 2011; 44:792-799.

32. Mohammadi Z. Chlorhexidine gluconate, its properties and applications in endodontics. Iranian Endod J 2008;2:113.

33. Basrani BR, Manek S, Fillery E. Using diazotization to characterize the effect of heat or sodium hypochlorite on 2.0\% chlorhexidine. J Endod 2009;35:1296-1299.

34. Guneser MB, Arslan D, Usumez A. Tissue dissolution ability of sodium hypochlorite activated by photon-initiated photoacoustic streaming technique. J Endod 2015;41:729732.

35. Golob BS, Olivi G, Vrabec M, El Feghali R, Parker S, Benedicenti S. Efficacy of Photon-Induced Photoacoustic Streaming in the reduction of Enterococcus faecalis within the root canal: different settings and different sodium hypochlorite concentrations. J Endod 2017;43:1730-1735.

Address correspondence to:

Hatice Buyukozer Ozkan, DDS, PhD

Department of Endodontics Faculty of Dentistry

Alanya Alaaddin Keykubat University Konakll mah. Mustafa Kemal Blv. No: 82 Alanya, Antalya 07425 Turkey

E-mail: hatice.buyukozer@gmail.com

Received: August 5, 2019. Accepted after revision: October 8, 2019. Published online: February 27, 2020. 